\title{
Lack of Predictable Race Shift in Heterodera glycines-Infested Field Plots
}

\author{
A. L. Colgrove, G. S. Smith, J. A. Wrather, R. D. Heinz, and T. L. Niblack, Department of Plant Microbiology \\ and Pathology, University of Missouri, Columbia 65211
}

\begin{abstract}
Colgrove, A. L., Smith, G. S., Wrather, J. A., Heinz, R. D., and Niblack, T. L. 2002. Lack of predictable race shift in Heterodera glycines-infested field plots. Plant Dis. 86:1101-1108.

Soybean cultivars with different sources of resistance to Heterodera glycines were grown at three locations initially infested with races 2,3 , and 6 in order to investigate $H$. glycines race shift in field populations. Each spring and fall, soil samples were taken from each plot and race tests were conducted to evaluate effects of cultivar and time of sampling. Field experiments were paired field plots rotated annually with corn since 1991. Cultivars included at the northern and central Missouri sites were Williams 82 (susceptible to H. glycines), Linford (PI 88788 source of resistance), MFA 9043 (Peking) replaced by Morsoy 9345 (Peking and PI 88788) from 1995 to 1997, and Jackson II (Peking + PI 88788) replaced by Asgrow 3431 (Peking and PI 88788) in 1996-97. Cultivars at the southern Missouri site were Essex or Hutcheson (susceptible to $\mathrm{H}$. glycines), Forrest (Peking), Hartwig (PI 437654), and Rhodes (PI 88788 + Peking). In 1995 , race tests were performed at four temperature regimes to determine temperature effects on race designations. Race shifts were not predictable based on the source of resistance of the soybean cultivar planted. Variability in female numbers on Lee 74 among tests caused changes in female indices (FI). Furthermore, race designations were influenced by the time of sampling and temperature at which the race tests were conducted. The variability of $H$. glycines populations in both field and greenhouse situations diminishes the value of race test results when making cultivar recommendations.
\end{abstract}

Additional keywords: female index, genetic variability, Glycine max, soybean cyst nematode

The soybean cyst nematode, Heterodera glycines Ichinohe, is the most economically damaging pathogen of soybean in the world (27) and is now found in most areas where soybean (Glycine max) is grown. The genetic variability of $H$. glycines populations has been amply demonstrated and complicates management of soybean in infested fields $(4,14,16-18,31,32)$. Although the use of host resistance is the most economically feasible and environmentally safe method of controlling $H$. glycines, a lack of durability of cultivar resistance has complicated its control $(4,32,34)$.

The genetic variability of populations of $H$. glycines was revealed soon after the release of resistant cultivars (22). In order to characterize heterogenous populations, a race scheme was developed in 1970 (6) and later expanded in 1988 (19). The female index (FI), defined as the percentage of females that develop on a differential soybean line relative to the standard susceptible, is used to determine the race identity of a population of $H$. glycines. A "-" reaction is recorded when FI $<10$; other-

Corresponding author: A. L. Colgrove

E-mail: alc6c5@mizzou.edu

Accepted for publication 15 May 2002.

Publication no. D-2002-0814-01R

(C) 2002 The American Phytopathological Society wise, the reaction is recorded as "+". Four differential soybean lines with resistance to $H$. glycines plus one standard susceptible line comprise the race test. The resulting pattern of "+" and "-_" ratings determines assignment to $H$. glycines race.

The current race characterization scheme serves to describe $H$. glycines populations in very broad terms because it permits intrarace variability, which may result in a less than definitive race designation $(14,16,18-20)$. When the FI is low, a small change in FI on one or more of the differentials can result in a change in race designation (e.g., $\mathrm{FI}=9$ versus $\mathrm{FI}=10$ on a differential gives a different race identity), whereas separate populations assigned to the same race can have vastly different FI (e.g., 10 to 100 or greater) on the same differential soybean line. Additionally, race tests themselves may not accurately measure the genetic composition of $H$. glycines populations as seen by variation among replications of race tests $(1,17,19,21)$. Attempts have been made to standardize the conditions under which race tests are conducted in order to improve consistency within and between labs; however, even under optimal conditions, inconsistency among race tests may still occur $(20,21)$.

Directional selection studies with resistant cultivars have shown that the frequency of virulent individuals in a population can change $(7,9,10,15,29)$. In greenhouse studies, the number of $H$. gly- cines individuals able to develop on a resistant host can increase after repeated rounds of selection. In field studies, race shifts have been reported with consistent use of resistant cultivars, which may reflect changes in the parasitic potential of the field populations. However, race shift may occur in directions other than what would be predicted based on the deployed source of resistance $(3,13)$. In greenhouse tests, temperature effects on race determinations for the same population were observed (T. L. Niblack, unpublished). The objective of this study was to investigate the predictability of race shift in field populations of $H$. glycines in order to determine the utility of race test results for cultivar recommendations.

\section{MATERIALS AND METHODS}

Host effect on race designation. A field experiment was established in Missouri in 1991 at three sites naturally infested with $H$. glycines. The sites were Edina, the northernmost location, Benton City, a central location, and Portageville, a location in southern Missouri. The experimental design was a split-split plot with four replications at each of the three locations. Main plots were tillage treatments (no-till, ridgetill, and conventional till consisting of fall and spring plowing and disking), subplots were dates of planting (early, midseason, and late, at approximately monthly intervals), and sub-sub-plots were soybean cultivars. In an adjacent area, identical main plots were established and planted to corn the first year. In subsequent years, the initial soybean and corn areas were planted to the other crop to reflect the corn/soybean rotation used by most Missouri grain producers. To differentiate these plots for communication, the plots will be designated soybean/corn or corn/soybean plots (e.g., Williams 82/corn or corn/Williams 82) depending on the rotation regimen. Main plot treatments were maintained each year that an area was planted to corn. In every year that soybean was planted to an area, the soybean cultivars planted in each sub-sub-plot were planted in the same sub-sub-plot location as in previous soybean years. Sub-subplots were $6.1 \mathrm{~m}$ long and were planted with four rows spaced $75 \mathrm{~cm}$ apart. In the first 3 years of the study, tillage and date of planting had no effect on FI in race tests; thus, these treatments were not considered in the analyses presented herein.

Soybean cultivars used at Edina and Benton City, the northern sites, were Wil- 
liams 82 (susceptible to $H$. glycines), Linford (PI 88788 source of resistance), MFA 9043 (Peking) replaced by Morsoy 9345 (Peking and PI 88788) from 1995 to 1997, and Jackson II (Peking and PI 88788) replaced by Asgrow 3431 (Peking and PI 88788) in 1996-97. In all cases, cultivars were replaced because they were no longer available, and replacements were selected based on similarity of genetic background.

Soybean cultivars used in Portageville were Essex (susceptible to $H$. glycines) replaced by Hutcheson (susceptible to $H$. glycines) from 1995 to 1997, Forrest (Peking), Hartwig (PI437654), and Rhodes (PI $88788+$ Peking).

Soil samples used for nematode analyses were collected in an arbitrary zigzag pattern from the center two rows of each subsub-plot. Soil cores were taken to a depth of $20 \mathrm{~cm}$ with a $2.5-\mathrm{cm}$-diameter probe. A $100 \mathrm{~cm}^{3}$ subsample of soil from each subsub-plot was processed as described previously (12) for extraction and enumeration of $H$. glycines eggs. The remaining soil from every plot sample representing the same cultivar treatment was bulked, mixed, and processed as described for race determination (12).

Initial soil samples were taken in spring of 1991 for race designation. In Edina, after two rotation cycles, soil samples were taken each spring and fall, from spring of 1994 to fall of 1997. In Portageville and Benton City, soil samples were taken each spring and fall beginning in 1991. After collection, soil samples were processed for determination of $H$. glycines race, as described in the following section.

Race determination. As described in Niblack et al. (12), subsamples of $100 \mathrm{~cm}^{3}$ from field soil samples were elutriated to extract cysts (fertilized females) and eggs. Eggs from cysts were concentrated and kept in suspension of 1,000 eggs per ml. The egg suspension was used to infest soil $\left(1,000\right.$ eggs per $\left.100 \mathrm{~cm}^{3}\right)$ subsequently planted with seedlings of Lee 74, Essex, and each of the soybean race differential lines (Pickett, Peking, PI 88788, and PI 90763). Experimental units were plastic crocks containing one race test, in which $18\left(100 \mathrm{~cm}^{3}\right)$ PVC tubes filled with infested soil were planted with one seedling per tube so that every soybean line was replicated three times. The crocks were suspended in water baths maintained at $27^{\circ} \mathrm{C}$. After 30 days, cysts were harvested from soybean roots with a high-pressure spray of water over nested 710/250 $\mu \mathrm{m}$ sieves and counted. The means of the three replications were then used to determine FI and race designation.

To facilitate communication of race test results, for the remainder of the text of this paper, the results of race tests will be discussed using the "+" or "-" ratings characteristic of each race in order on Pickett, Peking, PI 88788, and PI 90763, while figures will show the FI values. For example, for a race 3 (FI of less than 10 on all of the differentials), (-,-,-,-) would be shown; for a race 6 , the code would be $(+,-$, $-,-)(\mathrm{FI}=10$ or above on Pickett only); for a race 4 the pattern would be $(+,+,+,+)$ (FI $=10$ or above on all differentials); and so on for the rest of the races. This will distinguish the occurrence of race changes. Additionally, if race designations in individual plots are not addressed for a particular sample period, it can be assumed that the race designation did not change, and the race designation for those sample times would be the same as in the last test result shown.

Time of sampling test. In order to observe any differences in race test results based on time of sampling, Edina plots were sampled at two sample dates, in April and June 1994 (preplant and postplant). Soil samples were collected from the same location in Jackson II, Linford, MFA 9043, and Williams 82 plots on both sample dates as previously described for race designation. Samples taken were subjected to race tests performed as described above.

Test of consistency of race determination test conducted on the same soil sample. Race tests on soil samples taken in the fall of 1996 in Edina plots were repeated to investigate the consistency of race testing. Samples taken were subjected to race tests performed as described above. Tests were run in December 1996 and in January or February 1997.

Temperature effects on female development and race determination. Four temperature conditions were used to determine effect of temperature on $H$. glycines development in race tests. Temperature tank and bench top soil temperature readings were recorded daily for comparison. Three tests were conducted in water baths maintained at constant 24,27 , or $30^{\circ} \mathrm{C}$. The fourth test was conducted on the greenhouse bench top, which was subject to diurnal temperature fluctuations. Tests were done in March and May 1995, and again in January 1996, on soil collected at Edina and Benton City. Race test protocols were applied as described above except that there were nine replications instead of three; the mean of the female numbers

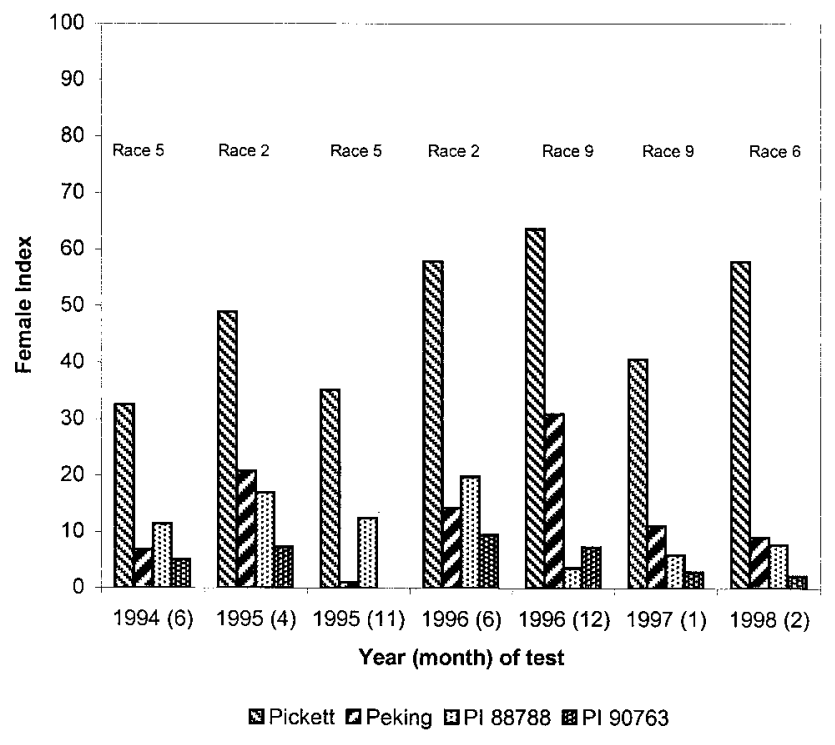

Fig. 1. Race determination tests of Heterodera glycines populations from Williams 82/corn plots at Edina, from 1994 to 1998. Williams 82 soybean is susceptible to $H$. glycines and was rotated annually with corn. The initial race designation of Edina plots was race 2. December 1996 and January 1997 tests were tests on the same soil sample, repeated to test consistency of race tests. Sample time results not shown were those where the race designation did not change.

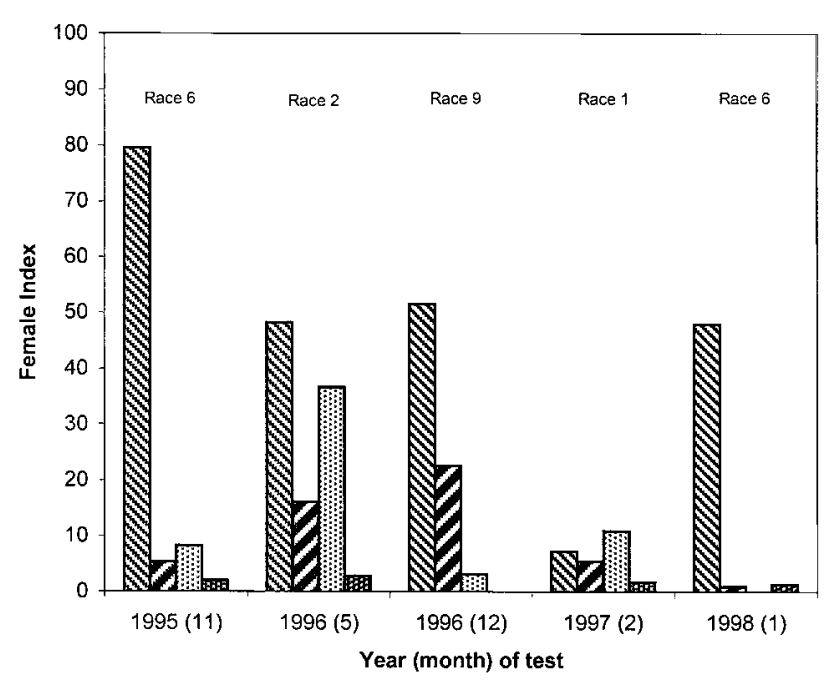

W Pickett DPeking QPI 88788 因PI 90763

Fig. 2. Race determination tests of Heterodera glycines populations from corn/Williams 82 plots at Edina, during the corn years, from 1995 to 1998. December 1996 and February 1997 tests were tests on the same soil sample, repeated to test consistency of race tests. Sample time results not shown were those where the race designation did not change. 
from the nine replications was used for comparison and for calculation of FI. In a separate test, the four temperature treatments were used to evaluate temperature effects on female numbers on Lee 74 and PI 88788 and differences that affect FI.

\section{RESULTS}

Host effect on race designation in Edina Williams 82/corn plots. The $H$. glycines population in Edina, the northernmost location, was initially determined to be a race $2(+,+,+,-)$ in 1991 . Over the course of the study, from 1991 to 1997 , in Williams 82/corn plots, race designations shifted from the original race 2 to a race 5 $(+,-,+,-)$, race 2 , race 5 , race 2 , race 9 $(+,+,-,-)$, and lastly, race $6(+,-,-,-)$. Changes in FI on PI 88788 and Peking effected changes in race designation, while female indices on Pickett and PI 90763 were always $\geq 10$ and $\leq 10$, respectively (Fig. 1).

Host effect on race designation in Edina corn/Williams 82 plots. In Edina corn/Williams 82 plots, the race designation went from the initial race $2(+,+,+,-)$ in 1991 to race $6(+,-,-,-)$, back to race 2 , then to race $9(+,+,-,-)$, and lastly to race 6 $(+,-,-,-)$. Changes in FI on Peking and PI 88788 affected race designation, while FI changes on Pickett and PI 90763 did not (Fig. 2).

Host effect on race designation in Edina Linford/corn plots. In Linford/corn plots, the race designation changed over the course of the study from the initial race $2(+,+,+,-)$ to race $9(+,+,-,-), 4(+,+,+,+)$, $2(+,+,+,-)$, and lastly, to race $5(+,-,+,-)$. Although changes in FI on Peking, PI 88788, and PI 90763 resulted in changes in race designation, overall the FI on these three differentials were fairly low and without large increases. Female indices on Pickett, however, had wide fluctuations without contributing to changes in race designation (Fig. 3).

Host effect on race designation in Edina corn/Linford plots. In the corn plots planted to Linford in the soybean years, race designation went from an initial race $2(+,+,+,-)$ to race $6(+,-,-,-), 2$ $(+,+,+,-), 9(+,+,-,-)$, and lastly, $15(+,-$, $+,+)$. PI 88788 FI again fluctuated, to as low as zero in the fall of 1996 , and contributed to race designation changes but overall remained low. The FI on Peking and PI 90763, when above 10, showed fairly low positive reactions, while FI on Pickett were always above 10 with wide fluctuations (Fig. 4).

The results of host effect in Jackson II and Morsoy 9043 plots at Edina are not presented for the sake of brevity, as results were similar to those previously discussed and not further illustrative.

Host effect on race designation in Benton City plots. The H. glycines population in Benton City, in central Missouri, initially tested as a race $3(-,-,-,-)$ in 1991 . After it was noted that $H$. glycines development on all differentials was initially low or absent, the Benton City soil samples from all plots were bulked before race tests were performed. The race designation did not deviate from a race $3(-,-,-$ ,-) until 1994, when the FI on Pickett increased from 0 to about 50, where it remained, resulting in a designation of race 6 $(+,-,-,-)$ for the last 2 years of the study. FI on the other differentials were again either zero or very low (Fig. 5).

Host effect on race designation in Portageville Essex/Hutcheson plots. In 1991, the $H$. glycines population in Portageville was initially designated a race $6(+,-,-,-)$. In the second year of the study, the race designation changed to race $4(+,+,+,+)$, with fairly substantial increases on Peking, PI 88788, and PI 90763 and a dramatic increase on Pickett with an FI of 135. Race test results from the fall of 1996 soil samples showed a return to a race 6 designation, but in the final race test, the population was again designated a race 4. Simultaneous changes in FI on Peking, PI 88788, and PI 90763 resulted in each race designation change (Fig. 6).

Host effect on race designation in Portageville Rhodes plots. In Portageville Rhodes plots, the race designation shifted from the initial race $6(+,-,-,-)$, with FI on Peking, PI 88788, and PI 90763 close to zero, to a race $4(+,+,+,+)$ in 1992 where it remained for the rest of the trial. While FI on Peking, PI 88788, and PI 90763 had no extreme changes, Pickett FI jumped from around 20 at the beginning of the study to over 100 in the second year, then in 1997 to almost 300 (Fig. 7).

The results of host effect on Hartwig and Forrest plots at Portageville are not presented for the sake of brevity as results were similar to those previously discussed.

Effect of time of sampling on race designation. In Edina plots, the time of sampling had an effect on race designation (Table 1). Samples taken in April 1994 yielded different race designations than June 1994 samples from all plots. In Jackson II plots, an increase in FI on Peking from 9 to 17 changed the race designation from $5(+,-,+,-)$ to $2(+,+,+,-)$. In Linford plots, FI on PI 88788 and PI 90763 decreased in June to change the race designation from race $4(+,+,+,+)$ to race $9(+,+,-,-)$.

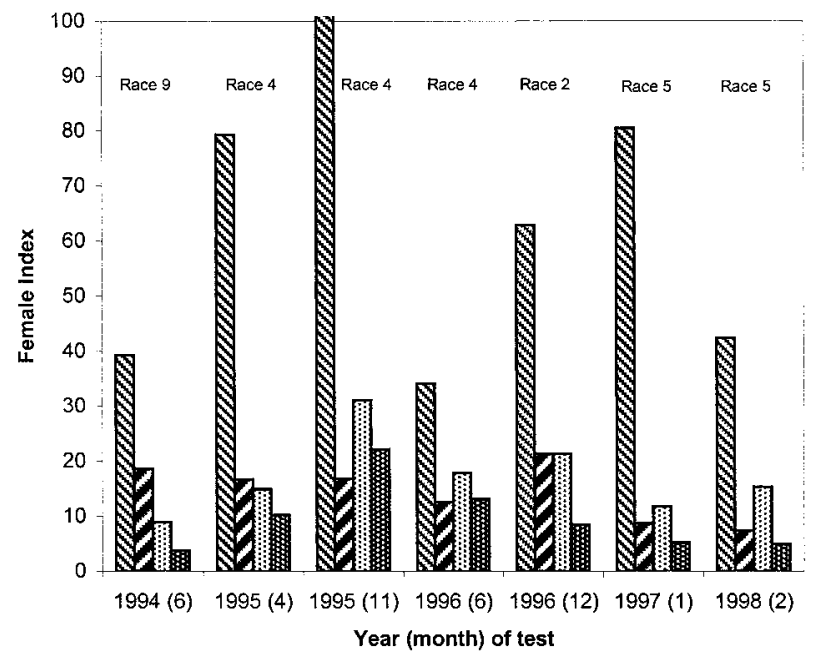

\$ Pickett DPeking 日PI 88788 国PI 90763

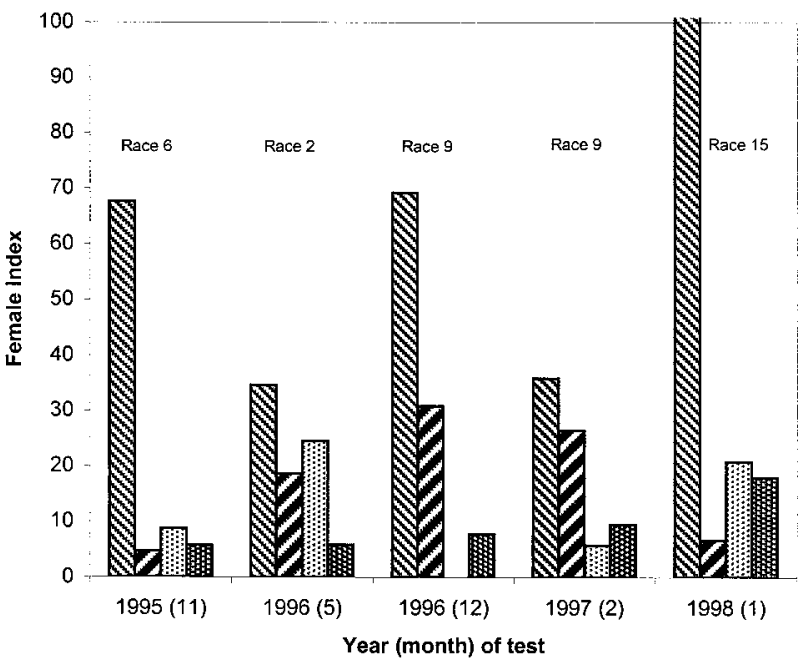

NPickett DPeking GPI 88788 四PI 90763
Fig. 3. Race determination tests on Heterodera glycines populations from Linford/corn plots at Edina, 1994 to 1998. The source of resistance in Linford is PI 88788. December 1996 and January 1997 tests were tests on the same soil sample, repeated to test consistency of race tests. Sample time results not shown were those for which the race designation did not change.
Fig. 4. Race determination tests of Heterodera glycines populations from corn/Linford plots at Edina, from 1995 to 1998. Linford soybean's source of resistance is PI 88788. December 1996 and February 1997 tests were tests on the same soil sample, repeated to test consistency of race tests. Sample time results not shown were those where the race designation did not change. 
In MFA 9043 plots, an FI decrease on PI 88788 resulted in a race $14(+,+,-,+)$ designation in June instead of the race 4 $(+,+,+,+)$, as with April samples. Lastly, in Williams 82 plots, an FI decrease on Peking altered the race designation from race $2(+,+,+,-)$ to race $5(+,-,+,-)$. In all plots sampled, the female numbers on Lee 74 differed among tests, ranging from a large difference as seen with Linford plots to a much smaller difference as found with samples from MFA 9043 plots (Table 1).

Effect of repeated race tests on race designation. Results of race tests that were repeated with soil samples collected in fall 1996 from Edina plots were not all consistent between tests. For Williams 82 plots planted to soybean in the first year, both tests resulted in a race $9(+,+,-,-)$ designation (Fig. 1). For Williams 82 plots planted to corn the first year, the first test resulted in a race $9(+,+,-,-)$, while the second test yielded a race $1(-,-,+,-)$ due to consequential changes in FI on Pickett, Peking, and PI 88788 (Fig. 2). For Linford plots, a change in FI on Peking caused the race designation to change from race $2(+,+,+,-)$ to race 5 $(+,-,+,-)$ (Fig. 3). In Linford plots planted to corn, both tests resulted in a race 9 (Fig. 4).

Temperature effects on female development and race determination. Relative to temperature tank readings, temperatures of soil exposed to nonconstant, ambient greenhouse conditions fluctuated widely. In March and May 1995, and in January 1996, soil temperatures in crocks on the greenhouse bench top ranged between 15 and $35^{\circ} \mathrm{C}, 17$ and $35^{\circ} \mathrm{C}$, and 14 and $28^{\circ} \mathrm{C}$, respectively. The temperature readings from the controlled temperature tanks were much less variable and were maintained with little deviation from the dictated temperatures $\left(24,27\right.$, or $\left.30^{\circ} \mathrm{C}\right)$.
Race determination of $H$. glycines was affected by soil temperature. In the March test of Edina soil, at diurnally fluctuating greenhouse temperature conditions with no temperature control, the test resulted in a race $6(+,-,-,-)$. At $24^{\circ} \mathrm{C}$, the result was a race $5(+,-,+,-)$ due to an FI on PI 88788 above 10 . At 27 and $30^{\circ} \mathrm{C}$, the FI on Peking and PI 90763 were also above 10, yielding race $4(+,+,+,+)$ designations. The differences in race designation were mainly due to small changes in FI (Fig. 8). In the test run in May on Edina soil, the results were all race 4 at every temperature condition (Fig. 9). Here, larger changes in FI were found that had no effect on race designation. In the test run in January on Edina soil, differences in race designation were found. These differences were again caused by small FI changes (Fig. 10). In Benton City samples, all tests resulted in race 3 designations. The FI were near zero in all tests. Therefore, the data are not shown.

In a separate test of female development on Lee 74 and PI 88788, female numbers on PI 88788 had no large changes, while numbers of females on Lee 74 increased greatly with temperature treatment (Fig. $11 \mathrm{~A}$ ). With no treatment, the FI was 11 , or "+", whereas at 24,27 , and $30^{\circ} \mathrm{C}$, the FI was below 10, or "-" (Fig. 11B). The increases on Lee 74 resulted in changes in FI on PI 88788 which could affect race designation; these changes were due almost exclusively to changes in female development on Lee 74 rather than to any appreciable change in female numbers on PI 88788.

\section{DISCUSSION}

Race designations of $H$. glycines populations changed in all plots, but the changes were not predictable based on host source of resistance. Several shifts in race designation occurred for Edina plots. In Linford plots at Edina, steady increases in FI on PI 88788 over the course of the study could be expected based on Linford's PI 88788 source of resistance. Selection pressure exerted by resistant soybean genotypes has been shown to change the frequency of virulent individuals in populations of $H$. glycines shown by an increase in development of females on resistant soybean $(10,25,31,32,34)$. In field populations, this change in gene frequencies can result in race shift, or a change in the race designation following a greenhouse race test. In this study, results were not as expected. No overall steady increases in FI on PI 88788 were demonstrated. In Linford/corn plots, the highest FI on PI 88788 was 32 in the fall of 1995 , and thereafter, it was lower and variable, but not substantially greater than 10 . These variations in FI on PI 88788 twice contributed to race designation changes. Results obtained from tests on corn/Linford plots were comparable. PI 88788 FI were never above 25 , and fluctuations contributed to race changes. As measured by race tests, consistent culture of Linford did not cause an expected increase in number of females on PI 88788 in Edina plots. Reactions on differentials other than PI 88788 also contributed to shifts in race designation of Linford plots in Edina. With no knowledge of resistance genes in Linford other than that derived from PI 88788, changes in numbers of individuals virulent on the other differentials would not be expected to be a factor. However, in Linford/corn plots, FI on PI 90763 contributed to shifts in race; based on the cultivar planted, race shifts due to FI changes not associated with

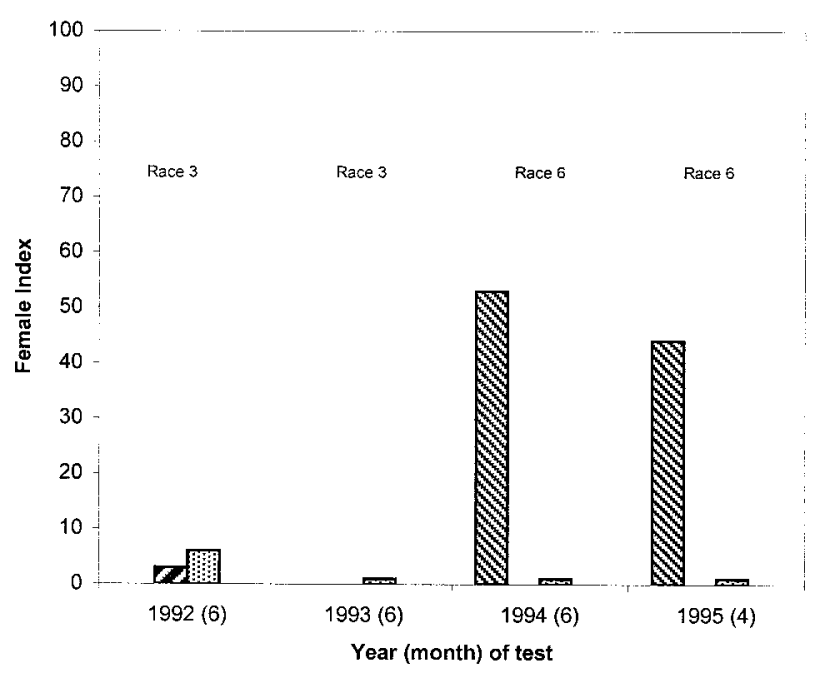

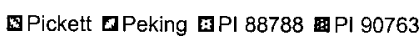

Fig. 5. Race determination tests of Heterodera glycines populations from Benton City plots, from 1992 to 1995 . All plots were combined due to an initial lack of reproduction on differentials and similarity of results. The initial race designation of Benton City plots was race 3. Sample time results not shown were those where the race designation did not change.

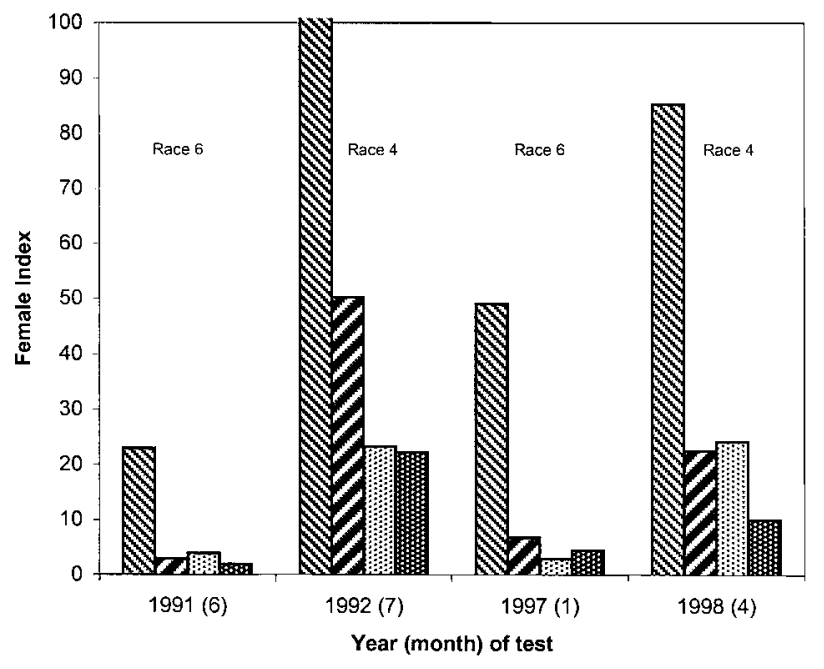

NPickett DPeking DPI 88788 明P 90763

Fig. 6. Race determination tests of Heterodera glycines populations from Essex/Hutcheson plots at Portageville, from 1991 to 1998. Essex and Hutcheson are susceptible to $H$. glycines. The initial race designation of Portageville plots was race 6. Sample time results not shown were those for which the race designation did not change. 
deployed resistance were not anticipated. Over the course of the study, Peking FI values were close to those on PI 88788, although low enough toward the end of the study to contribute to a change in race designation. Pickett, derived from Peking, had widely fluctuating FI, which did not influence race designation changes, as they were always $\geq 10$. However, the extreme increase in the FI on Pickett to 123 in the fall of 1995 is difficult to explain based on the cultivar planted. Repeated race tests on fall 1996 soil samples were inconsistent, yielding race designations of race 2 and race 5, which differ in their FI on Peking. In corn/Linford plots, variations in Peking and PI 90763 FI effected race changes. Pickett FI fluctuated widely and again peaked inexplicably. The variations in FI that effected race designation changes, or caused race shift, were not predictable. Although race designations of field populations changed with consistent use of the same resistant cultivar, the shifts involved differences not expected based on the cultivar grown. All in all, there was no discerni- ble effect of corn in corn years. These results exemplify the ambiguous quality of genetically variable $H$. glycines populations and emphasize the difficulty in making management decisions.

Attempts to show the occurrence of stabilizing selection when susceptible cultivars are consistently used have been unsuccessful $(24,33)$. Evidence of the occurrence of stabilizing selection in $H$. glycines populations would be a decrease in the numbers of individuals that can parasitize resistant hosts and, therefore, greater numbers of individuals that cannot. In Williams 82 plots, if stabilizing selection were predicted, the initial race $2(+,+,+,-)$ designation would be expected to shift toward a race $3(-,-,-,-)$, with steady decreases in FI on Pickett, Peking, and PI 88788. Seemingly random FI vacillations were instead characteristic, with no apparent trend to indicate a shift toward race 3 . In Williams 82 plots, if only final race test results were considered, it might appear that stabilizing selection occurred due to the low FI on Peking, PI 88788, and PI 90763. However, vacillations in FI of Pickett, Peking, and PI 88788 throughout the study obscure this interpretation. Because of the inconsistency, it is difficult to draw conclusions about the race shifts that occurred. Based on previous fluctuations, any trend would be difficult to predict.

Benton City samples revealed no predictable increase in virulence in the initially race $3(-,-,-,-)$ field population in all plots where resistant soybean was consistently planted. Although the race designation was a race $6(+,-,-,-)$ in 1994 , this was due to an increase on Pickett not expected based on the cultivars grown.

Portageville plots, like Edina and Benton City plots, were found to lack consistent directional selection. The $H$. glycines population from Portageville plots, initially designated race $6(+,-,-,-)$, at first could appear to be responding to selection pressure exerted by Rhodes' PI 88788 and Peking sources of resistance in a relatively straightforward manner, with a shift in race designation to race $4(+,+,+,+)$. However, the sampled population from Essex/

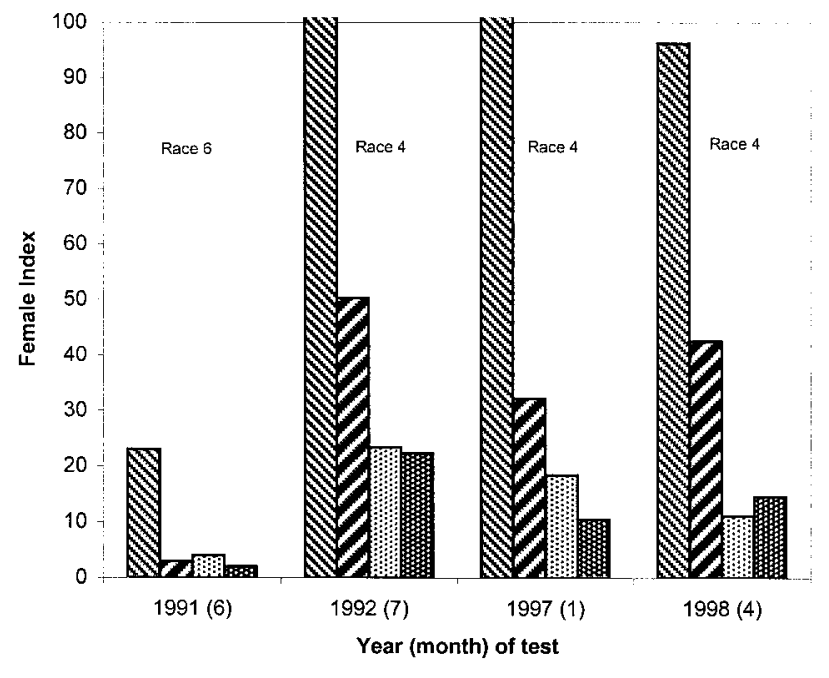

\$

Fig. 7. Race determination tests of Heterodera glycines populations from Rhodes plots at Portageville, from 1991 to 1998. The source of resistance of Rhodes soybean is PI 88788 and Peking. Sample time results not shown were those where the race designation did not change.

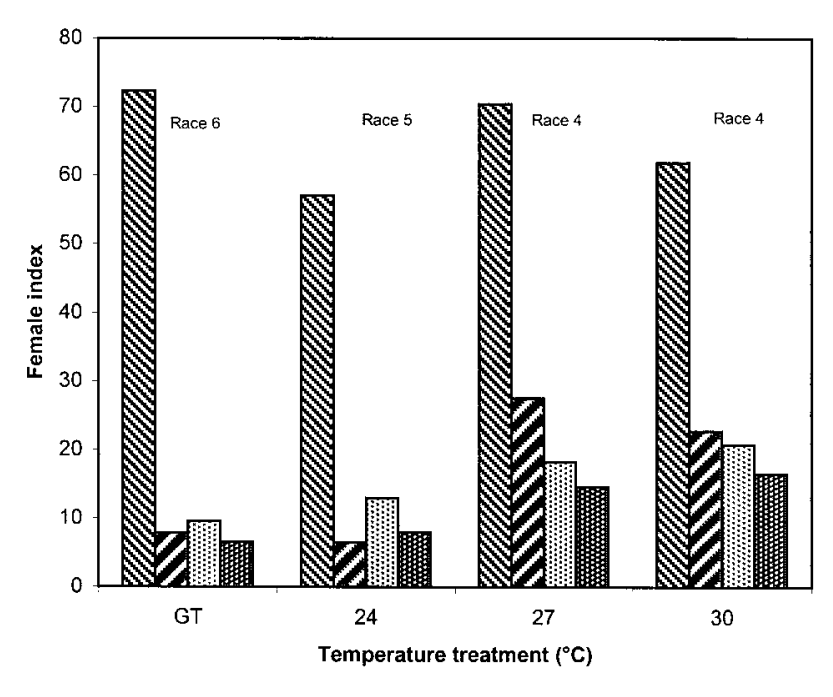

\$Pickett DPeking 日P| 88788 国PI 90763

Fig. 8. The effect of temperature on Heterodera glycines race determination tested in March 1995 on Edina soil samples. Race tests were conducted at three constant temperatures, 24,27 , or $30^{\circ} \mathrm{C}$, in water baths, and at nonconstant temperatures, or ambient greenhouse temperatures prevailing on the greenhouse bench top (GT).

Table 1. Heterodera glycines race test results from samples taken from the same plots in April (preplant) and June (postplant) in Edina, $\mathrm{MO}^{\mathrm{a}}$

\begin{tabular}{|c|c|c|c|c|c|c|c|}
\hline \multirow[b]{2}{*}{ Cultivar } & \multirow[b]{2}{*}{ Month of sampling } & \multirow[b]{2}{*}{ Females on Lee 74 (no.) } & \multicolumn{5}{|c|}{ Female indices $^{b}$} \\
\hline & & & Pickett & Peking & PI 88788 & PI 90763 & Race \\
\hline Jackson II & April 1994 & 198 & 35 & 9 & 18 & 5 & 5 \\
\hline Jackson II & June 1994 & 103 & 45 & 17 & 19 & 8 & 2 \\
\hline Linford & April 1994 & 263 & 42 & 16 & 15 & 10 & 4 \\
\hline Linford & June 1994 & 130 & 39 & 18 & 8 & 4 & 9 \\
\hline MFA 9043 & April 1994 & 265 & 112 & 38 & 12 & 16 & 4 \\
\hline MFA 9043 & June 1994 & 250 & 51 & 13 & 9 & 11 & 14 \\
\hline Williams 82 & April 1994 & 221 & 49 & 21 & 17 & 7 & 2 \\
\hline Williams 82 & June 1994 & 167 & 32 & 7 & 11 & 5 & 5 \\
\hline
\end{tabular}

${ }^{a}$ Data are means of three replications.

b Calculated by dividing the number of females that develop on the differential soybean line (Pickett, Peking, PI 88788, or PI 90763) by the number that develop on Lee 74, and converting to a percentage. 
Hutcheson plots also tested as a race 4 in final race tests, without the selection pressure of resistant varieties. The individual FI values were not notably different from those found with Rhodes plots, including the extreme Pickett increases in both plots. The consensus of changes in FI between the two plots minimizes the significance of the race 4 result in Rhodes plots. Additionally, the FI on PI 90763 increased without known selection pressure. Results from Portageville plots with susceptible soybean also corroborate Edina findings. Based on race tests from these field sites, there was an increase in reproduction on all race differentials in samples of field populations where susceptible soybean is consistently planted. These results are not consistent with stabilizing selection, or a shift toward decreased virulence, in these field populations. In plots with resistant cultivars, FI increases did not occur as predicted. Based on the data, evidence for any predictable shift in race is not strong.

In spite of attempts to standardize and optimize race tests for more consistent results, success in reducing variability in female numbers has been limited. The variability in numbers of females that develop and the effects on subsequent race designations have been widely reported $(1,3,16,19,20,30,35)$. Factors involved in the reproduction of females are many and do not appear to be predictably controllable. Time of sampling had a significant effect on race test results. Samples from the same plots collected at different times in the spring of 1994 were designated as different races. An argument could be made that the time of sampling should be standardized; however, to annually determine the correct sampling time in order to obtain the correct race designation is not feasible or incontrovertible. Any H. glycines sample taken from a field population and race tested cannot exactly represent the original population in the field. Only juveniles from hatched eggs that successfully develop during the race test are accounted for. Postplant samples may show host effects, preplant and postharvest samples may exhibit dormancy factors (28). These results diminish the strength of using race tests as a basis for cultivar recommendation.

Temperature has been shown to affect the development of $H$. glycines $(2,11)$. In this study, the temperature at which tests were run affected $H$. glycines development and race designation. On Lee 74, the numbers of females that develop affect FI, and therefore race designation. On PI 88788, the changes in FI with changes in temperature were mainly due to fluctuations in female numbers on Lee 74; female indices decreased with increases in female development on Lee 74. The "+" reaction in a race test would be interpreted differently than the "-", even though actual female development on PI 88788 changed very little. In the temperature effect on race test, at 27 and $30^{\circ} \mathrm{C}$, the race designation was a race 4 , the population type that develops on all race test differentials. At nonconstant temperature conditions and at $24^{\circ} \mathrm{C}$, the race designations were different, which could affect cultivar recommendations. Temperature can and should be controlled with water baths in the greenhouse when performing race tests to attempt to standardize tests. However, when female development itself is routinely inconsistent, variable race tests should not be unexpected.
When the race scheme was originally devised, the original Lee was believed to be susceptible to all known populations of soybean cyst nematode (6). When female numbers on Lee were found to be inconsistent, Lee 74 was recommended in an attempt to optimize race testing (20). However, these results, and others, have shown that Lee 74 may not have a stable reaction to $H$. glycines populations as well (26). Variation in female numbers with replications has been reported on both the susceptible and the differentials $(17,19,20,30)$. Several reasons have been given for the variations (20), which include the seeds, the inoculum, differential hatching, location and penetration of roots, and the sex ratio. While these factors may not all be controllable, inoculum levels should be standardized $(23,26 ;$ T. L. Niblack, unpublished). Whatever the cause of variability, when female numbers are inconsistent on both the standard susceptible and the differentials, race designations that result are questionable.

The ability to forecast pathogen response to cultivars deployed in the field would considerably improve $H$. glycines management options. The current race scheme provides general information regarding the genetic makeup of $H$. glycines field populations. A system of classification of races has been proposed, which ranks the level of susceptibility or resistance of soybean to $H$. glycines populations, to better describe field populations (23). However, if the race test itself does not accurately measure the $H$. glycines-soybean interaction, the usefulness of this classification and of race tests is diminished.

Besides the above factors that complicate attempts to make predictions on race

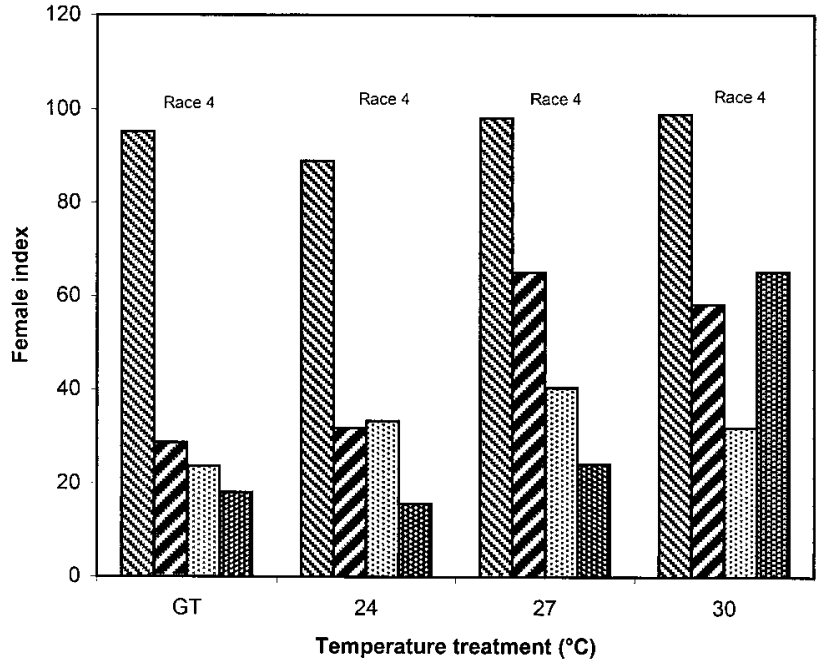

图Pickett DPeking BPI 88788 지 90763

Fig. 9. The effect of temperature on Heterodera glycines race determination tested in May 1995 on Edina soil. Race tests were conducted at three constant temperatures, 24,27 , or $30^{\circ} \mathrm{C}$, in water baths, and at nonconstant temperatures, or ambient greenhouse temperatures prevailing on the greenhouse bench top (GT).

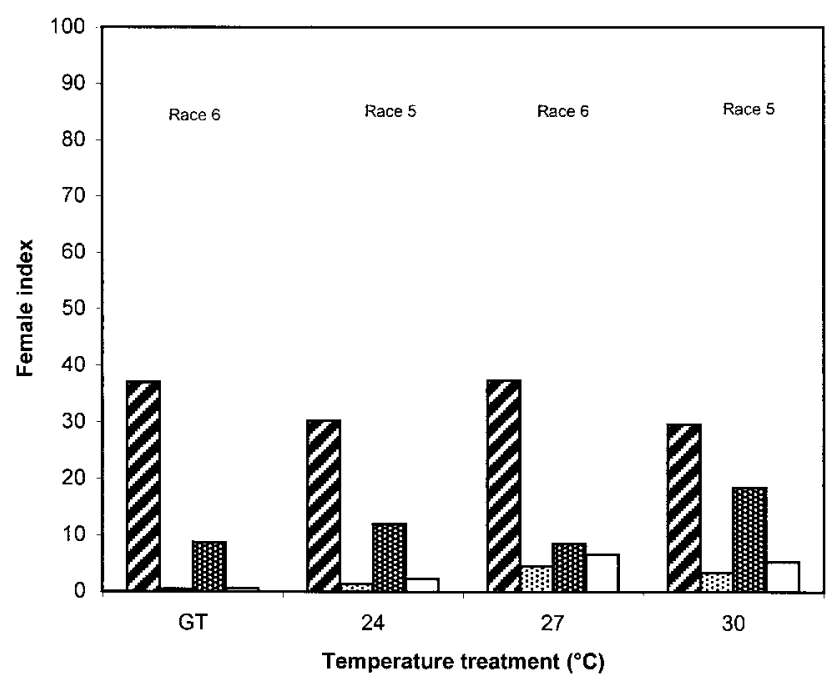

DPickett DPeking 国PI 88788 口PI 90763

Fig. 10. The effect of temperature on Heterodera glycines race determination tested in January 1996 on Edina soil. Race tests were conducted at three constant temperatures, 24,27 , or $30^{\circ} \mathrm{C}$, in water baths, and at nonconstant temperatures, or ambient greenhouse temperatures prevailing on the greenhouse bench top (GT). 
shift, the genetic background of the soybean cultivar deployed in the field may not be fully known. The complement of resistance genes present in the differentials is not believed to be the same as those in cultivars derived from them $(8,17)$. Therefore, $H$. glycines reaction to commercial cultivars cannot be expected to be the same as the differentials. Susceptible soybean, such as Williams 82 and Lee, have also been suspected of having genes for resistance $(5,7,9,13,20)$. This may further complicate prediction of race shift based on cultivars grown in the field and field populations tested in the greenhouse. The use of the differentials to gauge the parasitic abil-

A

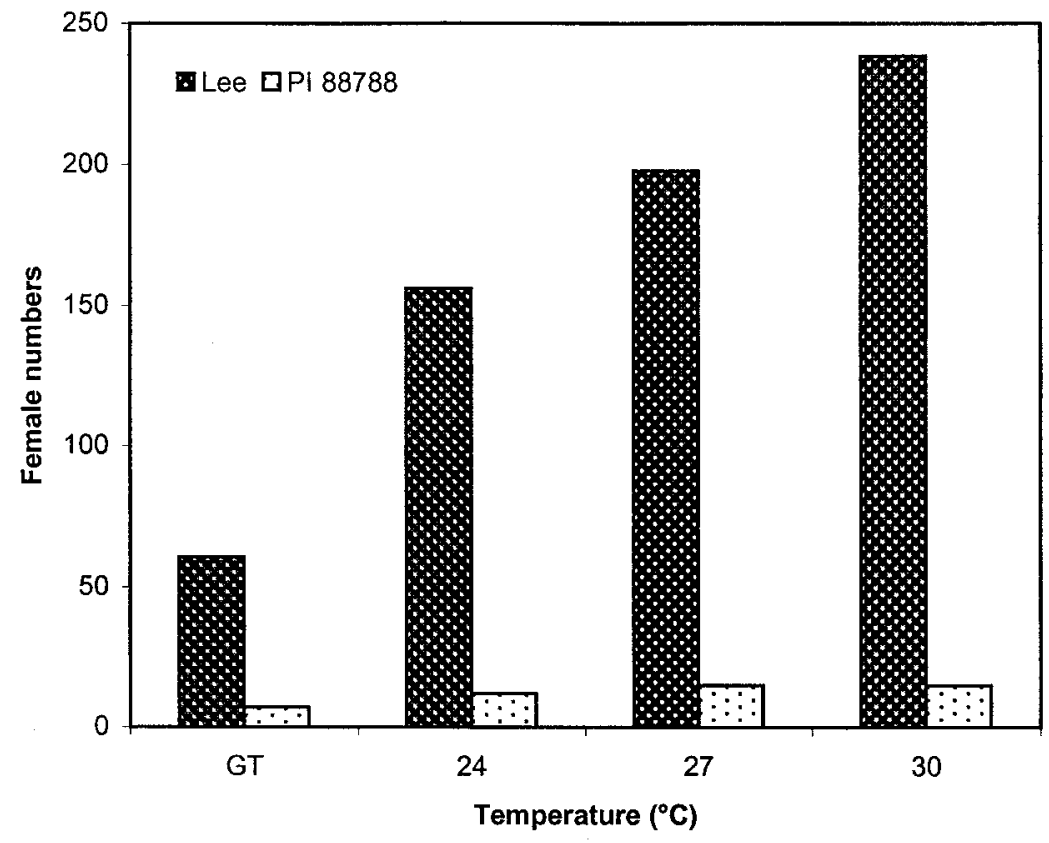

B

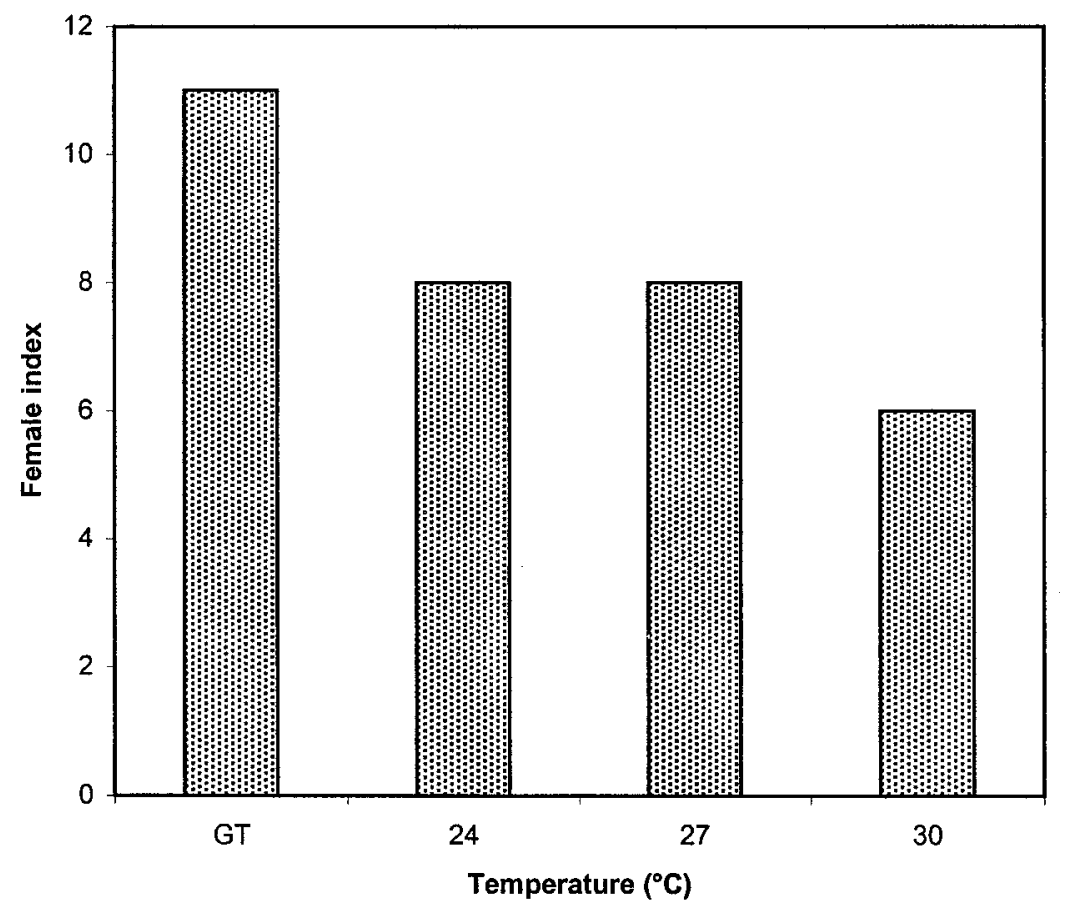

Fig. 11. The effect of temperature on Heterodera glycines development, at constant temperatures of $24,27,30^{\circ} \mathrm{C}$, and at nonconstant temperatures, or temperatures prevailing on the greenhouse bench top (GT), with the focus on one differential, PI 88788. A, Female numbers on Lee and PI 88788. B, Female indices on PI 88788.

ity of populations on cultivars derived from the same source of resistance as the differentials may not be appropriate. Increasingly, $H$. glycines-resistant cultivars have become more widely used; however, the practice of rotation with nonhosts should continue as a major part of $H$. glycines management programs.

This study has emphasized several problems found in regard to the $H$. glycines race scheme and its use to track population developments in $H$. glycines-infested soybean fields. Due to the inherent variability of both $H$. glycines populations and race tests, $H$. glycines race designations as measured by race tests may not accurately represent the parasitic ability of $H$. glycines populations. Although it has become widely accepted that $H$. glycines race designation can change over time, from year to year or season to season, it is now evident that race designation can also change from test to test. The lack of predictable characterization of genetically diverse $H$. glycines populations makes race shift forecasting an inexact science at best.

\section{ACKNOWLEDGMENTS}

We thank the Missouri Soybean Merchandising Council (Research Agreement \#077), the United States Department of Agriculture (Special Research Grants Program), and the Missouri Agricultural Experiment Station for support of this research. We are grateful for the long-term cooperation of our farmer cooperator in northern Missouri, Steve Miller, the staff of the University of Missouri Delta Center, Howard Mason, Kamron Colgrove, and Aaron Coburn, along with others involved in the Missouri Variety Trials for technical contributions.

\section{LITERATURE CITED}

1. Aeny, T. N., and Riggs, R. D. 1993. Susceptibility of soybean introductions to race $1,2,3$, and 4 of Heterodera glycines. J. Nematol. 25:34-37.

2. Alston, D. G., and Schmitt, D. P. 1988. Development of Heterodera glycines life stages as influenced by temperature. J. Nematol. 20:366-372.

3. Anand, S. C., Koenning, S. R., and Sharma, S. B. 1995. Effect of temporal deployment of different sources of resistance to soybean cyst nematode. J. Prod. Agric. 8:119-123.

4. Cloud, G. L., Riggs, R. D., and Caviness, C. E. 1988. Variability in host preference among field populations of Heterodera glycines. J. Nematol. 20:417-420.

5. Faghihi, J., Vierling, R. A., Halbrendt, J. M., Ferris, V. R., and Ferris, J. M. 1995. Resistance genes in a 'Williams 82' $\times$ 'Hartwig' soybean cross to an inbred line of Heterodera glycines. J. Nematol. 27:418-421.

6. Golden, A. M., Epps, J. M., Riggs, R. D., Duclos, L. A., Fox, J. A., and Bernard, R. L. 1970. Terminology and identity of infraspecific forms of the soybean cyst nematode (Heterodera glycines). Plant Dis. Rep. 54:544546.

7. Leudders, V. D. 1985. Selection and inbreeding of Heterodera glycines on Glycine max. J. Nematol. 17:400-404.

8. Leudders, V. D. 1989. Variable transfer of soybean genes for resistance to soybean cyst nematode. Crop Sci. 29:933-936.

9. Leudders, V. D., and Dropkin, V. H. 1983. Effect of secondary selection on cyst nematode reproduction on soybeans. Crop Sci. 
23:263-264.

10. McCann, J., Leudders, V. D., and Dropkin, V. H. 1982. Selection and reproduction of soybean cyst nematodes on resistant soybeans. Crop Sci. 22:78-80.

11. Melton, T. A., Jacobsen, B. J., and Noel, G. R. 1986. Effects of temperature on development of Heterodera glycines on Glycine max and Phaseolus vulgaris. J. Nematol. 18:468-474.

12. Niblack, T. L., Heinz, R. D., Smith, G. S., and Donald, P. A. 1993. Distribution, density, and diversity of Heterodera glycines in Missouri. J. Nematol. (suppl.) 25:880-886.

13. Noel, G. R., and Edwards, D. I. 1996. Population development of Heterodera glycines and soybean yield in soybean-maize rotations following introduction into a noninfested field. J. Nematol. 28:335-342.

14. Rao-Arelli, A. P., Wrather, J. A., and Anand, S. C. 1992. Genetic diversity among isolates of Heterodera glycines and sources of resistance in soybeans. Plant Dis. 76:894-896.

15. Riggs, R. D., Hamblen, M. L., and Rakes, L. 1977. Development of Heterodera glycines pathotypes as affected by soybean cultivars. J. Nematol. 9:312-318.

16. Riggs, R. D., Hamblen, M. L., and Rakes, L. 1981. Infra-species variation in reactions to hosts in Heterodera glycines populations. J. Nematol. 13:171-179.

17. Riggs, R. D., Rakes, L., and Dombek, D. 1995. Responses of soybean cultivars and breeding lines to races of Heterodera gly- cines. J. Nematol. (suppl.) 27:592-601.

18. Riggs, R. D., Rakes, L., and Elkins, R. 1991. Soybean cultivars resistant and susceptible to Heterodera glycines. J. Nematol. 23:584-592.

19. Riggs, R. D., and Schmitt, D. P. 1988. Complete characterization of the race scheme for Heterodera glycines. J. Nematol. 20:392-395.

20. Riggs, R. D., and Schmitt, D. P. 1991. Optimization of the Heterodera glycines race test procedure. J. Nematol. 23:149-154.

21. Riggs, R. D., Schmitt, D. P., and Noel, G. R. 1988. Variability in race tests with Heterodera glycines. J. Nematol. 20:565-572.

22. Ross, J. P. 1962. Physiological strains of Heterodera glycines. Plant Dis. Rep. 46:766769.

23. Schmitt, D. P., and Shannon, G. 1992. Differentiating soybean responses to Heterodera glycines races. Crop Sci. 32:275-277.

24. Sipes, B. S., Schmitt, D. P., and Barker, K. R. 1992. Fitness components and selection of biotypes of Heterodera glycines. J. Nematol. 24:415-424.

25. Triantaphyllou, A. C. 1975. Genetic structure of races of Heterodera glycines and inheritance of ability to reproduce on resistant soybeans. J. Nematol. 7:356-364.

26. Wang, S., Riggs, R. D., and Crippen, D. 1998. Soil infestation density affects the results of Heterodera glycines race tests. J. Nematol. (suppl.) 30:553-562.

27. Wrather, J. A., Anderson, T. R., Arsyad, D.
M., Gai, J., Ploper, L. D., Porta-Puglia, A Ram, H. H., and Yorinori, J. T. 1997. Soybean disease loss estimates for the top 10 soybean producing countries in 1994. Plant Dis. 81:107-110.

28. Yen, J. H., Niblack, T. L., and Weibold, W. J. 1995. Dormancy of Heterodera glycines in Missouri. J. Nematol. 27:153-163.

29. Young, L. D. 1984. Changes in the reproduction of Heterodera glycines on different lines of Glycine max. J. Nematol. 16:304-309.

30. Young, L. D. 1989. Use of statistics in race determination tests. J. Nematol. (suppl.) 21:544-546.

31. Young, L. D. 1992. Problems and strategies associated with long-term use of nematode resistant cultivars. J. Nematol. 24:228-233.

32. Young, L. D. 1998. Managing soybean resistance to Heterodera glycines. J. Nematol. (suppl.) 30:525-529.

33. Young, L. D., and Hartwig, E. E. 1988. Selection pressure on soybean cyst nematode from soybean cropping sequences. Crop Sci. 28:845-847.

34. Young, L. D., and Hartwig, E. E. 1992. Cropping sequence effects on soybean and Heterodera glycines. Plant Dis. 76:78-81.

35. Zhang, L., Dean, R. A., Knap, H. T., and Lewis, S. A. 1998. Diversity among a Heterodera glycines field isolate and derived inbreds based on RAPD analysis and reproduction on soybean genotypes. J. Nematol. (suppl.) 30:477-484. 